\title{
PERBANDINGAN UJI EFEKTIVITAS EKSTRAK BENGKUANG (PACHYRIZUS AROSUS) DAN DAUN SIRIH HIJAU (PIPER BETLE L.) TERHADAP BAKTERI PROPIONIBACTERIUM ACNES
}

\author{
I Nyoman Ehrich Lister \\ Fakultas Kedokteran \\ Universitas Prima Indonesia, Medan, Indonesia \\ Email: nyoman@unprimdn.ac.id
}

\begin{abstract}
Propionibacterium acnes is a gram-positive bacteria and consists of the Propionibacteriaceae family. Propionibacterium acnes is a bacteria that causes acne or acne vulgaris, a disease that is quite disturbing and gets the attention that occurs in adolescents and young adults. This research aimed to compare and determine the effectiveness of the extract of yam (Pachyrizus arosus) and green betel leaf (Piper betle L.) in inhibiting the growth of Propionibacterium acnes bacteria. The research variables were concentrations of yam extract (Pachyrizus arosus) 5\%, 10\%, 15\%, 20\% and green betel leaf (Piper betle L.) 1,5\%, 3\%, 5\%, 7,5\%. The results showed that there was an inhibiting zone against the growth of Propionibacterium acnes bacteria.
\end{abstract}

Keywords: Pachyrizus arosus, Piper betle L., Propionibacterium acnes, disc diffusion, acne vulgaris

\section{PENDAHULUAN}

Propionibacterium acne merupakan salah satu bakteri gram positif dan microbiota yang sering dijumpai pada kulit wajah, kulit kepala yang memiliki banyak kelenjar sebasea (Fitriani et al., 2018). Bakteri utama penyebab acne vulgaris adalah Propionibacterium acne dimana pada masa pubertas terjadi peningkatan aktivitas androgen memicu pertumbuhan kelenjar minyak sebaseous dan peningkatan produksi sebum (Armadany \& Pratiwi, 2018).

Bengkuang (Pachyrizus arosus) merupakan tanaman yang tumbuh di daerah tropis Amerika Tengah, juga terdapat di Indonesia yang banyak dibudidayakan di kawasan Sumatera
Utara, Asia Tengah, Jawa Barat, Sumatera Barat, Jawa Timur, Jawa Tengah (Cavenett, 2013). Bengkuang (Pachyrizus arosus) merupakan buah yang memiliki kandungan senyawa flavonoid, kuinon, tanin, saponin, alkaloid, dan triterpenoid sebagai antibakteri. Kandungan air pada bengkuang juga tinggi dan memiliki banyak serat (Faisal \& Zulfikri, 2020).

Bengkuang (Pachyrizus arosus) merupakan tanaman yang digunakan oleh manusia diberbagai bidang kecantikan, kesehatan, pangan, industri karena mengandung banyak khasiat (Rhofita, 2016). Pada penderita diabetes juga menggunakan bengkuang sebagai pengobatan tradisional dalam 
menurunkan kadar gula darah (Pertiwi \& Saputra, 2018)

Tanaman Sirih Hijau (Piper betle L.) tumbuh subur di sepanjang Asia tropis hingga Afrika Timur dan menyebar hampir di seluruh wilayah Thailand, Malaysia, Madagaskar, termasuk Indonesia (Carolia \& Noventi, 2016). Efektivitas daun sirih hijau (Piper betle L.) sebagai antibakteri telah terbukti sehingga digunakan sebagai pegobatan (Widyaningtias et al., 2014).

Kandungan kimia yang terdapat dalam sirih hijau (Piper betle L.) adalah saponin, polifenol, minyak atsari dan flavonoid. Kandungan minyak atsari mempengaruhi aroma daun sirih hijau (Piper betle L.) (Carolia \& Noventi, 2016).

Menurut hasil Penelitian yang telah dilakukan oleh Supari (2006) ekstrak biji bengkuang memiliki efektivitas terhadap bakteri Streptococcus mutans (Supari et al., 2016). Menurut hasil penelitian ekstrak daun sirih hijau (Piper betle $L$.) memiliki efek antibakteri dalam menghambat pertumbuhan Propionibacterium acnes (Carolia \& Noventi, 2016).

\section{METODE}

Penelitian ini menggunakan metode eksperimen laboratorium dengan rancangan penelitian Posttest Only Control Group Design.
Penelitian ini dilakukan pada bulan Maret 2020 - Juni 2020, di Laboratorium Mikrobiologi Fakultas Kedokteran Universitas Prima Indonesia.

Alat yang digunakan meliputi autoclave, gelas ukur, inkubator, timbangan analitik, plastic wrap, hotplate magnetic stirrer, erlenmeyer, rotary evaporator, pinset, mikropipet, kapas, cotton swab, lampu spiritus, tabung reaksi, wadah maserasi, spidol, cawan petri, masker, sarung tangan, kamera, alat tulis, label, lemari pengering, alat pengaduk, gelas kimia, blender, laminar air flow.

Bahan yang digunakan meliputi bengkuang (Pachyrizus arosus), daun sirih hijau (Piper betle L.), etanol 96\%, media Muller Hinton Agar, bakteri Propionibacterium acnes, akuades, antibiotik klindamisin disk (sebagai kontrol positif).

Sampel yang digunakan adalah bengkuang (Pachyrizus arosus) sebanyak 500 gram, daun sirih hijau (Piper betle L.) sebanyak 500 gram.

Teknik ekstraksi pada bengkuang (Pachyrizus arosus) dan daun sirih hijau (Piper betle L.) adalah maserasi. Bengkuang dicuci bersih dan dipotong kecil, kemudian direndam dalam bejana maserasi dengan etanol $96 \%$ selama lima hari serta diaduk beberapa kali untuk mendapatkan konsentrasi jenuh. 
Cairan maserat kemudian disaring untuk memperoleh maserat, kemudian menggunakan rotary evaporator untuk diuapkan dan dilanjutkan dengan waterbath dengan suuhu $\quad 60 \quad{ }^{0} \mathrm{C}$ (Yusriani, 2018).

Daun sirih hijau dicuci bersih, dikeringkan dan diiris menjadi serbuk kemudian dimaserasi selama 3 hari dengan etanol $96 \%$ dilakukan pengadukan sesekali, kemudian disaring dan maserat dikumpulkan. Maserat yang diperoleh dipekatkan dengan rotary evaporator pada suhu $40{ }^{\circ} \mathrm{C}$ (Lister et al., 2014).

Pembuatan media dengan serbuk MHA ditimbang sebanyak 38 gram dilarutkan dalam 1L akuades kemudian dipanaskan dan diaduk menggunakan hotplate magnetic stirrer hingga homogen (Hudaya et al., 2016). Kemudian tuang MHA kedalam cawan petri, dan dimasukkan kedalam lemari pendingin sampai mengeras.

Suspensikan bakteri sebanyak satu ose yang sudah disterilkan kemudian disentrifugasi menggunakan tabung sentrifugasi dengan $\mathrm{NaCl}$ fisiologis $0,9 \%$ sebanyak dua kali dan dihomogenkan. Setelah itu, kekeruhan disetarakan dengan satuan baku $M c$ Farland $1,5 \times 10^{8} \mathrm{CFU} / \mathrm{mL}$ (Tri Mulyani et al., 2017).

Uji aktivitas antibakteri etanol bengkuang dan daun sirih hijau menggunakan metode disc diffusion Kirby-Bauer. Suspensi bakteri digoreskan diatas media uji pada media cawan petri dengan menggunakan kapas ulas steril kemudian diputar beberapa kali dan dilakukan sebanyak dua kali. Cakram kertas berisi konsentrasi ekstrak bengkuang, daun sirih hijau, kontrol positif, kontrol negatif diletakkan ditempat di atas permukaan media yang sesuai dengan posisi yang telah diatur. Kemudian inkubasi media tersebut dalam suhu $30{ }^{\circ} \mathrm{C}$ selama 24 jam, setelah itu dilakukan pengamatan terhadap diameter zona hambat menggunakan jangka sorong dalam satuan milimeter (Sari et al., 2017).

Tabel 1. Klasifikasi Daya Hambat Pertumbuhan Bakteri David dan Stout (1971) (Sarwendah et al., 2020)

\begin{tabular}{cc}
\hline $\begin{array}{c}\text { Diameter daya } \\
\text { hambat bakteri } \\
(\mathbf{m m})\end{array}$ & Kategori \\
\hline$\geq 20 \mathrm{~mm}$ & Sangat kuat \\
$10-20 \mathrm{~mm}$ & Kuat \\
$5-10 \mathrm{~mm}$ & Sedang \\
$\leq 5 \mathrm{~mm}$ & Lemah \\
\hline
\end{tabular}

Analisa data yang telah diperoleh dalam penelitian ini dianalisis secara statistika dengan perangkat SPSS menggunakan uji ANOVA. 
HASIL DAN PEMBAHASAN

Hasil

\section{Uji Fitokimia Bengkuang dan Daun} Sirih Hijau

Hasil uji fitokimia ekstrak bengkuang (Pachyrizus arosus) dengan pelarut etanol positif mengandung banyak kandungan flavonoid, alkaloid, terpenoid, tanin, dan saponin. Ekstrak daun sirih hijau dengan pelarut etanol positif mengandung banyak kandungan flavonoid, steroid, tanin dan saponin.

Tabel 2. Hasil Uji Fitokimia Ekstrak Bengkuang dan Daun Sirih Hijau

\begin{tabular}{cclcc}
\hline No & $\begin{array}{c}\text { Senyawa } \\
\text { Metabolit } \\
\text { Sekunder }\end{array}$ & \multicolumn{1}{c}{ Pereaksi } & $\begin{array}{c}\text { Hasil } \\
\text { Bengkuang }\end{array}$ & $\begin{array}{c}\text { Hasil Daun } \\
\text { Sirih Hijau }\end{array}$ \\
\hline 1 & Flavonoid & $\mathrm{FeCl}_{3} 5 \%$ & + & + \\
& & $\mathrm{Mg}_{\mathrm{HCl}}$ & + & + \\
& & $\mathrm{H}_{2} \mathrm{SO}_{4}$ & + & + \\
2 & Alkaloid & Bouchardart & + & - \\
& & Maeyer & + & - \\
3 & Terpenoid & Salkowsky & + & - \\
& & Liebermann-Burchard & + & + \\
4 & Steroid & Salkowsky & - & + \\
& & Liebermann-Burchard & - & + \\
5 & Tanin & FeCl & + & + \\
6 & Saponin & Aquadest +alcohol & + & + \\
& & $96 \%+\mathrm{HCl} 2 \mathrm{~N}$ & & + \\
\hline
\end{tabular}

Efektivitas Ekstrak Bengkuang dalam menghambat Propionibacterium acnes pertumbuhan

Hasil pengukuran zona hambat pada ekstrak bengkuang terhadap Propionibacterium acne sebagai berikut.

\begin{tabular}{|c|c|c|}
\hline Tabel 3. & $\begin{array}{l}\text { sil Pengukuran } \\
\text { ha Hambat } \\
\text { ggkuang } \\
\text { pionibacterium che }\end{array}$ & $\begin{array}{l}\text { Diameter } \\
\text { Ekstrak } \\
\text { terhadap } \\
\text { acnes }\end{array}$ \\
\hline Perlakuan & $\begin{array}{l}\text { Rata-rata Diame } \\
\text { Hambat } \pm \text { SD }\end{array}$ & $\begin{array}{l}\text { ter Zona } \\
(\mathrm{mm})\end{array}$ \\
\hline $20 \%$ & $24,267 \pm 1$ & \\
\hline $15 \%$ & $22,353 \pm 0$ & \\
\hline $10 \%$ & $22,24 \pm 0,4$ & 543 \\
\hline $5 \%$ & $19,467 \pm 0$ & \\
\hline $\mathrm{K}+$ & $35,917 \pm 1$ & \\
\hline K- & $0,00 \pm 0,0$ & \\
\hline
\end{tabular}

Berdasarkan hasil pengukuran diameter zona hambat ekstrak bengkuang terhadap Propionibacterium acnes pada Tabel 3 diatas, rata-rata zona hambat yang terbentuk adalah 24,267 mm pada konsentrasi 20\%, 22,353 mm pada konsentrasi 15\%, 22,24 mm pada konsentrasi 10\%, 19,467 mm pada konsentrasi 5\%. Berdasarkan kriteria David dan Stout didapatkan bila, diameter zona hambat yang dibentuk berukuran $\leq 5 \mathrm{~mm}$ maka ekstrak tersebut memiliki daya hambat lemah, 5-10 mm memiliki daya hambat sedang, 10-20 $\mathrm{mm}$ memiliki daya hambat sangat kuat, dan $\geq 20 \mathrm{~mm}$ memiliki daya hambat 
sangat kuat. Dari kriteria tersebut maka ekstrak bengkuang konsentrasi 5\% termasuk ke dalam kriteria sifat daya hambat kuat, konsentrasi 10\%, 15\%, $20 \%$ termasuk ke dalam kriteria daya hambat sangat kuat.

Berdasarkan penelitian Novitawati dan Rahminiwati (2018) bahwa biji bengkuang terbukti memiliki aktivitas antibakteri terhadap bakteri Escherichia coli Selanjutnya Yusriani (2018) menunjukkan bahwa pemberian ekstrak bengkuang potensial dalam menekan pertumbuhan Propionibacterium acnes.

Efektivitas Ekstrak Daun Sirih Hijau dalam menghambat pertumbuhan Propionibacterium acnes

Hasil pengukuran zona hambat pada ekstrak daun sirih hijau terhadap Propionibacterium acne sebagai berikut.

Tabel 4. Hasil Pengukuran Diameter Zona Hambat Ekstrak Daun Sirih Hijau terhadap Propionibacterium acnes

\begin{tabular}{cc}
\hline Perlakuan & $\begin{array}{c}\text { Rata-rata Diameter Zona } \\
\text { Hambat } \pm \text { SD }(\mathrm{mm})\end{array}$ \\
\hline $7,5 \%$ & $16,487 \pm 1,613$ \\
$5 \%$ & $16,740 \pm 2,181$ \\
$3 \%$ & $13,103 \pm 2,356$ \\
$1,5 \%$ & $9,893 \pm 0,962$ \\
$\mathrm{~K}+$ & $20,713 \pm 0,973$ \\
$\mathrm{~K}-$ & $0,00 \pm 0,00$ \\
\hline
\end{tabular}

Berdasarkan hasil pengukuran diameter zona hambat ekstrak daun sirih hijau terhadap Propionibacterium acnes pada Tabel 4 diatas, rata-rata zona hambat yang terbentuk adalah 16,487 $\mathrm{mm}$ pada konsentrasi 7,5\%, 16,740 $\mathrm{mm}$ pada konsentrasi 5\%, 13,103 mm pada konsentrasi 3\%, 9,893 $\mathrm{mm}$ pada konsentrasi $1,5 \%$. Berdasarkan kriteria David dan Stout, maka ekstrak daun sirih hijau pada konsentrasi 7,5\%, 5\%, dan 3\% termasuk kriteria sifat daya hambat kuat, sedangkan konsentrasi $1,5 \%$ termasuk kriteria sifat daya hambat sedang.

Berdasarkan penelitian yang dilakukan oleh Kursia (2016) bahwa daun sirih terbukti memiliki aktivitas antibakteri terhadap bakteri Staphylococcus epidermidis (Kursia et al., 2016). Selanjutnya Novita (2016) menunjukkan bahwa ekstrak daun sirih hijau memiliki aktivitas antibakteri dalam menghambat pertumbuhan Propionibacterium acne (Carolia \& Noventi, 2016).

Perbandingan Efektvitas Ekstrak Bengkuang dan Daun Sirih Hijau terhadap pertumbuhan Propionibacterium acnes

Perbandingan hasil pengukuran zona hambat pada ekstrak bengkuang dan daun sirih hijau terhadap Propionibacterium acnes sebagai berikut. 
Tabel 5. Perbandingan Efektivitas Ekstrak Bengkuang dan Daun Sirih Hijau terhadap Propionibacterium acnes

\begin{tabular}{cccc}
\hline \multirow{2}{*}{ Ekstrak } & Konsentrasi & $\begin{array}{c}\text { Rata-rata Diameter Zona Hambat } \pm \\
\text { SD }(\mathbf{m m})\end{array}$ & \multirow{2}{*}{ Nilai $\boldsymbol{P}$} \\
\hline \multirow{3}{*}{ Bengkuang } & $20 \%$ & $24,267 \pm 1,569$ & 0.00 \\
& $15 \%$ & $22,353 \pm 0,848$ & 0.00 \\
& $10 \%$ & $22,24 \pm 0,4543$ & 0.00 \\
& $5 \%$ & $19,467 \pm 0,503$ & 0.00 \\
Daun Sirih & $7,5 \%$ & $16,487 \pm 1,613$ & 0.00 \\
Hijau & $5 \%$ & $16,740 \pm 2,181$ & 0.00 \\
& $3 \%$ & $13,103 \pm 2,356$ & 0.00 \\
& $1,5 \%$ & $9,893 \pm 0,962$ & 0.00 \\
\hline
\end{tabular}

Tabel diatas menunjukkan bahwa terdapat perbedaan yang secara statistik bermakna antara masing-masing sampel pada berbagai konsentrasi dan sampel (nilai $P<0.05$ ) di uji dengan One Way Anova.

Berdasarkan hasil penelitian yang diperoleh bahwa ekstrak bengkuang (Pachyrizus arosus) dan daun sirih hijau (Piper betle L.) memiliki efek antibakteri terhadap Propionibacterium acnes. Diantara kedua ekstrak, didapatkan bahwa ekstrak bengkuang (Pachyrizus arosus) memiliki efektivitas antibakteri yang lebih kuat dibandingkan ekstrak daun sirih hijau (Piper betle L.).

\section{Pembahasan}

Klasifikasi daya hambat menurut David dan Stout, dapat disimpulkan bahwa ekstrak bengkuang pada konsentrasi 20\%, 15\%, 10\% termasuk kategori sangat kuat, konsentrasi 5\% termasuk kategori kuat, sedangkan ekstrak daun sirih hijau pada konsentrasi 7,5\%, 5\%,3\% termasuk kategori kuat, konsentrasi $1,5 \%$ termasuk kategori sedang.

Berdasarkan penelitian Qin dan Sihotang (2020) bahwa senyawa flavonoid, alkaloid, terpenoid, tanin dan saponin merupakan senyawa yang berpotensi sebagai antibakteri (Qin \& Sihotang, 2020). Flavonoid dapat menghambat banyak reaksi oksidasi, secara enzim maupun non enzim (Hilma et al., 2016). Mekanisme kerja flavonoid dengan merusak membran sel dan mendenaturasi protein sel bakteri tanpa dapat diperbaiki lagi (Carolia \& Noventi, 2016).

Menurut Nimah (2012) alkaloid sebagai antibakteri dengan mekanisme kerja menghambat dinding sel sehingga sel lisis (Nimah et al., 2012). Terpenoid merupakan senyawa yang memiliki aktivitas antibakteri dengan mekanisme menganggu proses pembentukan membran dan dinding sel bakteri sehingga kedua organ tersebut tidak terbentuk dengan sempurna (Supari et al., 2016). 
Senyawa tanin termasuk golongan polifenol yang diduga dapat mengkerutkan membran sel atau dinding sel yang mengakibatkan sel tidak dapat melakukan aktivitas hidup dikarenakan permeabilitas sel terganggu (Afiff \& Amilah, 2017). Saponin sebagai antibakteri dengan zat aktif permukaan menyerupai detergen yang dapat menurunkan tegangan pada dinding sel bakteri sehingga permeabilitas membran rusak (Ernawati \& Sari, 2015). Mekanisme kerja saponin sebagai antibakteri dalam merusak permeabilitas membran sel, sehingga komponen penting dalam sel bakteri akan keluar berupa asam nukleat, protein, asam nukleotida (Khasanah et al., 2014).

\section{KESIMPULAN DAN SARAN}

\section{Kesimpulan}

Berdasarkan hasil penelitian ini ekstrak bengkuang (Pachyrizus arosus) dan daun sirih hijau (Piper betle L.) memiliki efektivitas dalam menghambat pertumbuhan Propionibacterium acnes. Berdasarkan hasil penelitian ini diperoleh bahwa Efektivitas ekstrak bengkuang (Pachyrizus arosus) lebih efektif dalam menghambat pertumbuhan Propionibacterium acnes dibandingkan ekstrak daun sirih hijau (Piper betle L.) melalui pengamatan terhadap diameter zona hambat menggunakan jangka sorong dalam satuan milimeter.

\section{Saran}

Bagi peneliti selanjutnya untuk dilakukan perlakuan lebih lanjut dalam memperbesar atau mempersempit selang waktu konsentrasi pada ekstrak bengkuang dan daun sirih hijau terhadap beberapa jenis bakteri dan jamur pathogen.

\section{DAFTAR PUSTAKA}

Afiff, F. ., \& Amilah, S. (2017). Efektivitas ekstrak daun mengkudu (Morinda citrifolia L.) dan daun sirih merah (Piper crocatum Ruiz \& Pav) terhadap zona hambat pertumbuhan Staphylococcus aureus. STIGMA: Jurnal Matematika dan Ilmu Pengetahuan Alam Unipa, 10(01), 12-16.

https://doi.org/10.36456/stigma.vol1 0.no1.a635

Armadany, F. I., \& Pratiwi, A. (2018). Uji aktivitas antibakteri sediaan krim anti jerawat ekstrak etanol terpurifikasi daun sirih ( Piper betle L .) dengan Basis Vanishing Cream terhadap Propionibacterium acne. Journal Pharmauho, 4(September), 30.

Carolia, N., \& Noventi, W. (2016). Potensi ekstrak daun sirih hijau ( Piper betle L .) sebagai alternatif terapi Acne vulgaris The Potential of Green Sirih Leaf ( Piper betle L .) for Alternative Therapy Acne vulgaris. Studi Pendidikan Dokter Fakultas Kedokteran Universitas Lampung, Vol. 5(1), Hal. 140.

Cavenett. (2013). Summary for Policymakers. In Intergovernmental Panel on Climate Change (Ed.), Climate Change 2013 - The Physical Science Basis (Vol. 53, Issue 9, pp. 1-30). Cambridge University Press. https://doi.org/10.1017/CBO9781107 415324.004

Chenoweth, C. E., \& Saint, S. (2016). 
Urinary tract infections. In Infectious Disease Clinics of North America. https://doi.org/10.1016/j.idc.2016.07. 007

Ernawati, \& Sari, K. (2015). (Chemical compound content and antibacterial activity of avocado (Persea americana P.Mill) Peel Extract On Vibrio alginolyticus Bacteria). V, 203-211.

Faisal, H. M. dan, \& Zulfikri. (2020). Efektifitas berkumur larutan ekstrak bengkuang (Pachyrizus erosus) terhadap Plak Indeks Siswa Kelas IV dan V SDN 15 Ampang Gadang Kecamatan Ampek Angkek Kabupaten Agam Tahun 2019. Ensiklopedia of Journal, 2(2), 236242.

Fitriani, U., Budiastuti, A., \& Widodo, A. (2018). Pengaruh Pemakaian masker madu terhadap derajat keparahan akne vulgaris. Jurnal Kedokteran Diponegoro, 7(2), 885891.

Hermiyanty, H. (2016). Faktor risiko infeksi saluran kemih di bagian rawat inap RSU Mokopido Tolitoli Tahun 2012. Healthy Tadulako.

Hilma, R., Nurianti, S., \& Fadli, H. (2016). Aktivitas antioksidan dan toksisitas ekstrak etanol bonggol pisang nangka (Musa Paradisiaca Formatypicaatu). 1th CelscitechUMRI 2016, 1(September), 55-61.

Hudaya, A., Radiastuti, N., Sukandar, D., \& Djajanegara, I. (2016). Uji aktivitas antibakteri ekstrak air bunga kecombrang terhadap bakteri E. coli dan S. aureus sebagai Bahan Pangan Fungsional. Al-Kauniyah Jurnal Biologi, 7(1), 9-15. https://doi.org/10.15408/kauniyah.v7 i1.2707

Irawan, E., \& Mulyana, H. (2018). Faktor-faktor penyebab infeksi saluran kemih (ISK). Prosiding Seminar Nasional Dan Diseminasi Penelitian Kesehatan.

Khasanah, I., Sarwiyono, \& Surjowardojo, P. (2014). Ekstrak etanol daun kersen (Muntingia calabura L .) sebagai antibakteri terhadap Streptococcus agalactiae Penyebab Mastitis Subklinis pada Sapi Perah Imro'atul Khasanah, Sarwiyono dan Puguh Surjowardojo Bagian Produksi Ternak Fakultas Peternakan . Uni. Jurnal Ternak Tropika, 15(2), 7-14.

Kursia, S., Lebang, J. S., Taebe, B., Burhan, A., Rahim, W. O. ., \& Nursamsiar. (2016). Uji aktivitas antibakteri ekstrak etilasetat daun sirih hijau (Piper betle L.) terhadap bakteri Staphylococcus epidermidis. Indonesian Journal of Pharmaceutical Science and Technology, 3(2), 72-77.

Lister, N. E., Viany, R. D., Nasution, A. N., Zein, R., Manjang, Y., \& Munaf, E. (2014). Antimicrobial activities of methanol extract of sirih merah (Piper crocatum L.) lleaf. Journal of Chemical and Pharmaceutical Research, 6(12), 650-654.

Nimah, S., Ruf, W., \& Trianto, A. (2012). Uji bioaktivitas ekstrak teripang pasir (Holothuria Scabra) terhadap bakteri Pseudomonas aeruginosa dan Bacillus cereus. Jurnal Pengolahan Dan Bioteknologi Hasil Perikanan, 1(1), 9-17.

Novitawati, N. C., \& Rahminiwati, M. dan O. K. (2018). Daya antibakteri serum kelinci yang di beri ekstrak etanol $70 \%$ biji bengkuang terhadap bakteri Escherichia Coli.

Perry, A. G., Potter, P. A., \& Ostendorf, W. R. (2014). Clinical nursing skills \& techniques. In Elsevier.

Pertiwi, R., \& Saputra, H. M. (2018). Pengaruh perasan umbi bengkuang (Pachyrhizus erosus L.) terhadap gambaran histopatologi lambung mencit (Mus musculus L.) dengan model tukak lambung reza. Jurnal Farmasi Dan Ilmu Kefarmasian Indonesia, 5(2), 56-61.

Putri, R. A., Armiyati, Y., \& Supriyono, M. (2015). Faktor - faktor yang berpengaruh terhadap kejadian infeksi saluran kemih pada pasien rawat inap. In Karya Ilmiah.

Qin, S., \& Sihotang, S. (2020). Efektifitas ekstrak daun alpukat 
(Persea americana mill) terhadap proipionibacterium acens dan pityrosporum ovale. Acnes, Propionibacterium Ovale, Pityrosporum, 3(2), 75-81.

Rhofita, E. I. (2016). Analisis kualitas dasar tepung bengkuang hasil pengeringan sistem pemanas ganda. Journal Politeknik, 8(4), 11-16.

Sari.E.W.P., Satyabakti, P. (2015). Perbedaan risiko infeksi nosokomial saluran kemih berdasarkan kateterisasi urin, umur, dan diabetes melitus. Departemen Epidemiologi Fakultas Kesehatan Masyarakat Universitas Airlangga.

Sari, R., Muhani, M., \& Fajriaty, I. (2017). Uji aktivitas antibakteri ekstrak etanol daun gaharu (Aquilaria microcarpa Baill.) Terhadap Bakteri Staphylococcus aureus dan Proteus mirabilis Antibacterial Activity of Ethanolic Leaves Extract of Agarwood (Aquilaria microcarpa Baill.) Against Staphyloco. Pharm Sci Res, 4(3), 143-154.

Sarwendah, S., Yusliana, Y., G Laia, H. C., Daely, P. J., \& Chiuman, L. (2020). Uji Daya hambat antibakteri air perasan daging buah nanas (Ananas comosus (L) Merr Var. Queen) terhadap bakteri Propionibacterium acnes. Jurnal Biologi Tropis, 20(1), 87. https://doi.org/10.29303/jbt.v20i1.10 55

Selano, M. K., Panjaitan, R. N., \& Raharjo, S. B. (2019). Hubungan kepatuhan perawat melaksanakan standar prosedur operasional perawatan kateter menetap dengan angka kejadian infeksi saluran kemih. Jurnal Smart Keperawatan. https://doi.org/10.34310/jskp.v6i1.21 6

Storme, O., Tirán Saucedo, J., GarciaMora, A., Dehesa-Dávila, M., \& Naber, K. G. (2019). Risk factors and predisposing conditions for urinary tract infection. Therapeutic Advances in Urology. https://doi.org/10.1177/17562872188
14382

Supari, I. H., Leman, M. A., \& Zuliari, K. (2016). Efektivitas antibakteri ekstrak biji bengkuang (Pachyrrhizus erosus) Terhadap Pertumbuhan Streptococcus mutans secara In Vitro. Journal Pharmcon, 5(3), 3339.

Suryarinilsih, Y., -, D., \& Aulia, M. (2018). Lamanya penggunaan kateter dengan kejadian infeksi saluran kemih pada pasien terpasang kateter. Jurnal Persatuan Perawat Nasional Indonesia (JPPNI). https://doi.org/10.32419/jppni.v2i3.9 2

Tri Mulyani, Y. W., Hidayat, D., Isbiantoro, I., \& Fatimah, Y. (2017). Ekstrak daun katuk (Sauropus androgynus (L) Merr) sebagai antibakteri terhadap Propionibacterium acnes dan Staphylococcus epidermidis. JFL: Jurnal Farmasi Lampung, 6(2), 4655. https://doi.org/10.37090/jfl.v6i2.21

Widyaningtias, Yustiantara, \& Paramita. (2014). Uji aktivitas antibakteri ekstrak terpurifikasi daun sirih hijau (Piper betle L.) Terhadap Bakteri Propionibacterium acnes. Jurnal Farmasi Udayana, 50-53.

Yusriani. (2018). Uji aktivitas krim ekstrak bengkoang (Pachyrhizus erosus) terhadap bakteri Propionibacterium acnes. Journal Farmasi Yamasi Makassar, 2 no 1, 427-441. 